\title{
Journal of Applied Pharmaceutical Science
}

Available online at www.japsonline.com

ISSN: 2231-3354

Received on: 06-06-2012

Revised on: 10-06-2012

Accepted on: 15-06-2012

DO: 10.7324/J APS.2012.2707

KlotoéJ R, KoudbkponH, Fanou VBA, Fah L, LokoF, DandjessoC, Dougnon TV

Ecole P dytechni qued'A bomey-Calavi (EPAC), Département deBidoge Humaine, Laboratoi re deRedhercheen Bidoge Appliquée(LARBA), Uni versi téd'A bomey-Calavi (UAC), 01 BP 2009 Cotonau, Bénin.

\section{Sacramento TI, AtègboJ J-M,}

DrameneK

$F$ acultédes Sci ences \& T echni ques (FAST) , Département deP hysi dogie animale, Laboratoi re de

Pharmacologie, Uni versitéd'A bomeyCalavi (UAC), 01 BP 526 Cotonou, Bénin.

\section{Edorh AP}

$F$ acultédes Sciences et Techniques (FAST), Département deBiochimie đ BidogeCellulaire, Uni versité d'A bomey-Calavi, (UAC) , 01 BP 526 Cotonou, Bénin.

\section{For Correspondence}

\section{Dougnon TV}

Ecole P dytechni qued'A bomey-Calavi (EPAC), Département deBiologe Humai ne, Laboratoi re deRechercheen Biologe Appliquée( LARBA), Uni versi téd'A bomey-Calavi (UAC), 01 BP 2009 Cotonau, Bénin.

Te. 00 ( 229) 97736446/64675119.

\section{Hemostatic potential of the sap of Musa sapientum L. (Musaceae)}

\author{
KlotoéJ R, Daugnon TV, SacramentoTI, DandjessoC, Edarh AP, Kouddkpon \\ H, FanouVBA, Fah L, AtègboJ M, LokoF and DramaneK.
}

Keywords: Musa sapientum, coagulation, hemostatic, protein network.

\section{INTRODUCTION}

Musa sapientum commonly known as 'banana' is an herbaceous plant of Musaceae family. It has been used for the treatment of gastric ulcer, hypertension, diarrhea, dysentery and diabetes in India (Dikshit et al., 2012). The antidiabetic effect of the leaves, stem, fruit, root and flower has been demonstrated (Pari and Umamaheswari, 2000; Adewoye and al., 2009, 2011). Anti-ulcerative properties have been highlighted in green fruits (Pannangpetch et al., 2001; Prabha et al., 2011). Musa spientum is also used in the treatment of excessive menstruation with Canna indica L. var. speciosa(Partha, 2007). The fruit of M. sapientum showed antimicrobial properties (Fagbemi et al., 2009). 
Musa sapientum L. called "Goukokwé" in Benin language (Fon) (de Souza, 1988; Akoègninou et al., 2006) is one of the most widely used medicinal species in the treatment of hemorrhage. The freshly collected sap from the trunk or juice which collects inside the trunk is used for vaginal lavage and / or per os with the addition of kaolin or not. The juice obtained by looting the terminal bud of the regime, is used in oral administration with the addition of kaolin. The fresh sap is also used as local hemostatic for the treatment of external wounds and this plant has been reported by other authors for its hemostatic and wound healing. Thus, in Brazil, its sap is used for treatment of bleeding (Albuquerque et al., 2007). The aqueous extract of the fruit of Musasapientum is used in India for the treatment of wounds (Agarwal et al., 2009; Atzingen, 2011). A species of the same genus (Musa paradisiaca L.) was reported in Brazil for the same properties (Borges et al., 2005). Despite this wide use as antihemorrhagic, no study has been performed so far on the hemostatic properties of this plant. This is why the objective of this study is to investigate the effect of Musa sapientum on hematological and biochemical parameters in order to understand its mechanism of action.

\section{MATERIAL AND METHODS}

\section{Vegetal material}

M. sapientum's sap was collected directly in sterile bottles after a cut in the trunk of the plant. It was centrifuged at $5000 \mathrm{rpm}$ for 5 minutes and the supernatant was stored at $4{ }^{\circ} \mathrm{C}$ in Eppendorftubes.

\section{Blood product (whole blood, plasma and serum)}

Blood samples were obtained by venipuncture from normal adult human who were volunteers for the study. The blood was collected in a dry tube and a tube containing sodium citrate (0.109 M). Plasma and serum were obtained respectively by centrifugation tubes containing citrate and dry tubes.
Milk

It was about whole milk brand "President" commercially available.

\section{Phytochemical analyses}

Phytochemical analyses of $M$. sapientum sap was conducted in the Research Laboratory of Pharmacognosy and Essential Oils from the University of Abomey-Calavi, on the basis of differential staining reactions and precipitation using the method by Houghton \& Raman (1998).

The different reactions about active compounds are summarized in Table I.

\section{Morphological evaluations}

Action of M. sapientumsap on plasma and serum was evaluated in the Research Laboratory of Applied Biology from the University of Abomey-Calavi (UAC) by macroscopic and microscopic observations.

$100 \mu \mathrm{l}$ of sap were added to $1 \mathrm{ml}$ of plasma or serum sample. Each tube was observed macroscopically before and after addition of sap.

Microscopic observations were performed on a microscope mounted on a CETI BELGIUM camera connected to a computer screen. Microscopic preparations were carried out between slide and coverslip by adding $10 \mu \mathrm{l}$ of sap to $50 \mu \mathrm{l}$ of plasma.

\section{Evaluation of astringent properties: precipitation of milk test}

We used two (02) glass test tubes with one for test and one for control. M. sapientum was collected in $1 \mathrm{ml}$ test tube and 1 $\mathrm{ml}$ of distilled water was put in the control tube. $100 \mu \mathrm{L}$ milk was then added in each of the two tubes. We homogenized it, allowed to stand for 03 minutes and centrifuged for 01 minute at $3000 \mathrm{rpm}$. The presence or absence of pellet was noted.

Table. 1: Phytochemical analyses.

\begin{tabular}{|c|c|}
\hline Classes of active substances & Specific reagents and reactions \\
\hline Alkaloids & Mayer $\longrightarrow$ yellowish precipitate \\
\hline Quinone derivatives & Born-Träger $\longrightarrow$ purplish red color \\
\hline Cathetic and gallic tannins & $\begin{array}{l}\text {-Reagent of Stiasny } \longrightarrow \longrightarrow \text { pink precipitate } \\
\text { - Saturation by acetate of } \mathrm{Na}+\mathrm{FeCl}_{3} \longrightarrow \text { blue-dark green or black }\end{array}$ \\
\hline Flavonoids & Shinoda $\longrightarrow$ orange color, red or purple \\
\hline Cyanogenic derived & Guignard (picric acide) $\rightarrow$ brown coloration \\
\hline Steroids and triterpenoids & $\begin{array}{l}\text { - Libermann-Burchard } \longrightarrow \text { violet-blue or green } \\
\text { - Kedde } \longrightarrow \text { reddish purple or red wine }\end{array}$ \\
\hline Saponins & Determination of the Foam Index (MI): positive test if MI >100 \\
\hline Anthocyanins & Red coloration of the filtrate increased in acid medium and blue-violet in alkaline medium \\
\hline Leuco-anthocyanins & Chloridric alcohol $\longrightarrow \quad$ cherry red color \\
\hline $\begin{array}{l}\text { Mucilages } \\
\text { Reducing compounds } \\
\text { Coumarins } \\
\text { Anthracenederivatives }\end{array}$ & 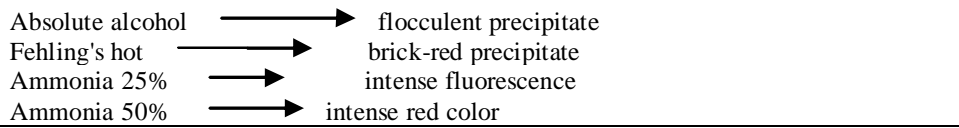 \\
\hline
\end{tabular}

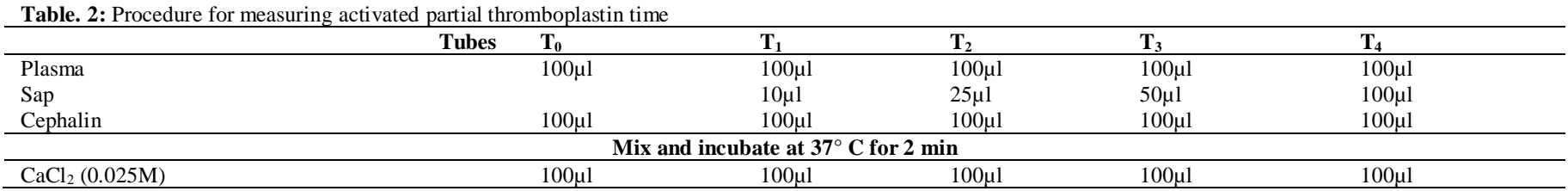


Table. 3: Procedure for measuring Quick Time.

\begin{tabular}{|c|c|c|c|c|c|}
\hline Tubes & $\mathbf{T}_{\mathbf{0}}$ & $\mathbf{T}_{1}$ & $\mathbf{T}_{2}$ & $\mathbf{T}_{3}$ & $\mathbf{T}_{4}$ \\
\hline Plasma & $100 \mu \mathrm{l}$ & $100 \mu \mathrm{l}$ & $100 \mu \mathrm{l}$ & $100 \mu \mathrm{l}$ & $100 \mu \mathrm{l}$ \\
\hline Sap & & $10 \mu 1$ & $25 \mu \mathrm{l}$ & $50 \mu 1$ & $100 \mu \mathrm{l}$ \\
\hline \multicolumn{6}{|c|}{ Incubate at $37^{\circ} \mathrm{C}$ for 01 minute } \\
\hline Calcium thromboplastin & $200 \mu \mathrm{l}$ & $200 \mu \mathrm{l}$ & $200 \mu 1$ & $200 \mu \mathrm{l}$ & $200 \mu \mathrm{l}$ \\
\hline
\end{tabular}

Table. 4: Dilution range of serum pool from the sap of $M$. sapientum.

\begin{tabular}{|c|c|c|c|c|c|c|c|c|c|c|c|c|c|c|c|}
\hline \multirow[t]{2}{*}{ Dilution } & \multirow[t]{2}{*}{ T0 } & \multicolumn{2}{|c|}{ T5\% } & \multicolumn{2}{|c|}{ T10\% } & \multicolumn{2}{|c|}{$\mathrm{T} 15 \%$} & \multicolumn{2}{|c|}{ T20\% } & \multicolumn{2}{|c|}{$\mathrm{T} 25 \%$} & \multicolumn{2}{|c|}{$\mathrm{T} 40 \%$} & \multicolumn{2}{|c|}{ T50\% } \\
\hline & & Test & cont & Test & cont & Test & cont & Test & cont & Test & cont & Test & cont & Test & cont \\
\hline Serum Pool & $1000 \mu \mathrm{l}$ & $950 \mu 1$ & $950 \mu 1$ & $900 \mu \mathrm{l}$ & $900 \mu \mathrm{l}$ & $850 \mu \mathrm{l}$ & $850 \mu 1$ & $800 \mu \mathrm{l}$ & $800 \mu \mathrm{l}$ & $750 \mu 1$ & $750 \mu 1$ & $600 \mu 1$ & $600 \mu \mathrm{l}$ & $500 \mu 1$ & $500 \mu \mathrm{l}$ \\
\hline Sap & - & $50 \mu \mathrm{l}$ & - & $100 \mu \mathrm{l}$ & - & $150 \mu \mathrm{l}$ & - & $200 \mu 1$ & - & $250 \mu 1$ & - & $400 \mu 1$ & - & $500 \mu 1$ & - \\
\hline $\mathrm{NaCl}(0.9 \%)$ & - & - & $50 \mu \mathrm{l}$ & - & $100 \mu \mathrm{l}$ & - & $150 \mu 1$ & - & $200 \mu \mathrm{l}$ & - & $250 \mu 1$ & - & $400 \mu 1$ & - & $500 \mu 1$ \\
\hline
\end{tabular}

Leave the mixture for $15 \mathrm{~min}$ and centrifuge at $300 \mathrm{rpm}$ for $5 \mathrm{~min}$

\section{Measurement of Clotting Time (CT)}

We used five tubes numbered T0, T1, T2, T3 and T4. T0 is the control tube and T1, T2, T3, T4 received respectively 10, 25, 50 and $100 \mu \mathrm{l}$ of Musa sapientum. After a minute in a water bath at $37^{\circ} \mathrm{C}, 500 \mu \mathrm{l}$ of blood freshly collected was added to each tube. The timer is immediately triggered and CT of each tube is noted.

\section{Measurement of activated partial thromboplastin time (aPTT)}

We used five glass hemolysis tubes. The procedure used is summarized in Table II. Tube T0 is the control tube and tubes $\mathrm{T} 1, \mathrm{~T} 2, \mathrm{~T} 3$ and T4 are the test tubes (which have received different doses of $M$. sapientum). We measure the time of appearance of the clot by tipping every five seconds the tubes at $90^{\circ} \mathrm{C}$. The test is repeated five times and averaged.

\section{Time measurement of prothrombin time (PT)}

Five glass hemolysis tubes were used. The protocol used is summarized in Table III. T0 is control tube and T1, T2, T3 and T4 are the test tubes. We measure the time of onset of the coagulum by tilting every five seconds tubes at $90^{\circ} \mathrm{C}$. The tests were repeated five times and averages were determined.

\section{Determination of Total Proteins}

The sap of M. sapientum was diluted with a pool of fresh normal human serum in a dilution range from $0 \%$ to $50 \%$ (Table IV). Total proteins were performed by adding $20 \mu \mathrm{l}$ of supernatant from each tube to $1000 \mu \mathrm{l}$ of biuret reagent. After $30 \mathrm{~min}$ incubation in to dark, reading was done in a spectrophotometer at $550 \mathrm{~nm}$ against reagent blank. The tests were repeated five times and the average was determined.

\section{Statistical Analyses}

The mean and standard deviations of the different data sets were calculated.The percentage reduction (PR) that evaluates the gain time of the test compared to control was calculated by the following formula:

$\mathrm{PR}=($ Time of control -time test $) /($ time of control $) \times 100$

The time difference between test and control were compared by the Student test. The significance level was set at $\mathrm{P}$ $<0.05$.
These various operations were performed using the software Excel 2007 and XL-Stata version 2011.

\section{RESULTS}

Morphological evaluation: Effect of Musa sapientum sap on the plasma and serum

Before adding the sap of $M$. sapientum, plasma and serum collected in the tubes were perfectly clear. After the addition of sap, we observed very rapidly $(<1 \mathrm{~s})$ formation in a network of white substance in the plasma (Figure 1) and serum (Figure 2). This substance is irreversibly formed. Microscopic observations showed that contact between the plasma and sap results in the formation of a substance that is in the form of concentric filaments at a magnification of x100 (Figure 3).

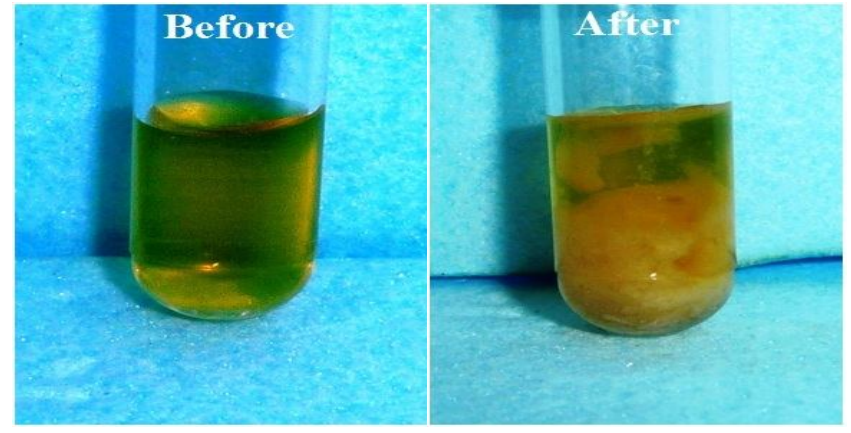

Fig. 1: Appearence of the plasma before and after addition of the sap of $M$. sapientum.

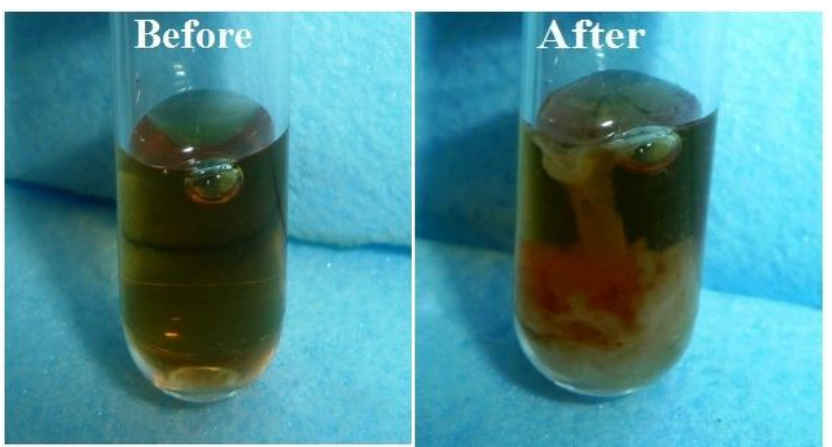

Fig. 2: Appearence of the serum before and after addition of the sap of $M$. sapientum. 


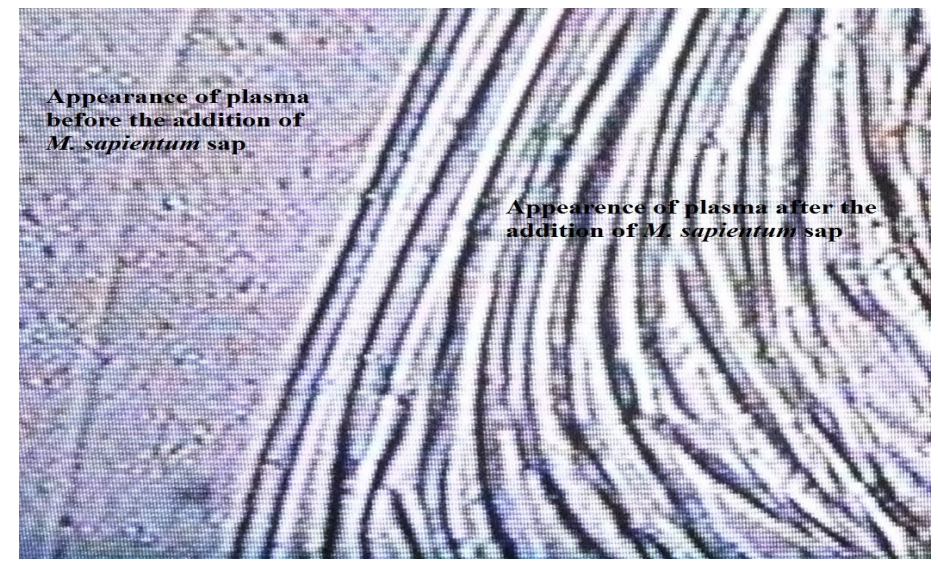

Fig. 3: Microscopic view of the plasma before and after contact with the sap of $M$. sapientum(magnification $\mathrm{x} 100$ ).

\section{Studies astringent properties: precipitation test milk}

We observed the formation of a pellet in the tube containing the sap while the control tube remained clear (Figure 4). Sap of M. sapientum has precipitated milk proteins, so it has an astringent property.
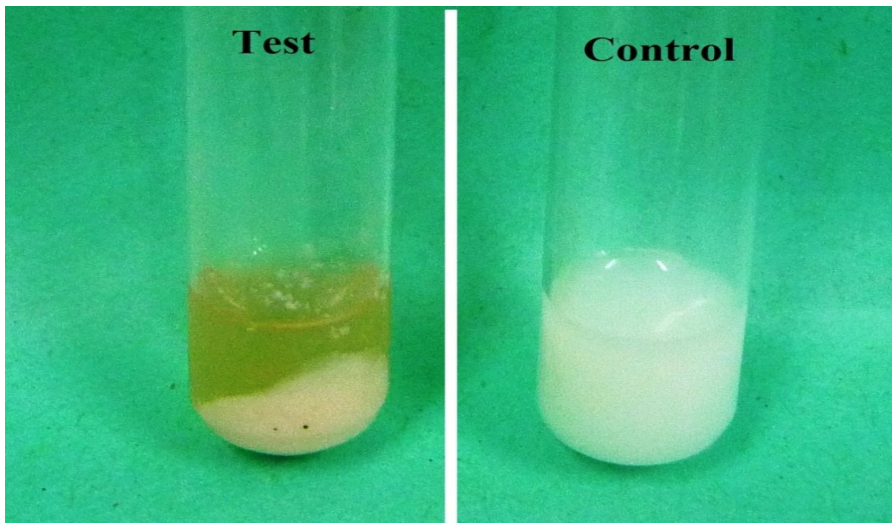

Fig. 4 : Precipitation of milk proteins under the action of the sap of $M$. sapientum

\section{Measurement of Clotting Time (CT)}

Averages of CT obtained are presented in Figure 5. Sap significantly reducedCT $(\mathrm{p}<0.05)$ with percentages ranging from $18.33 \%$ to $27.22 \%$.

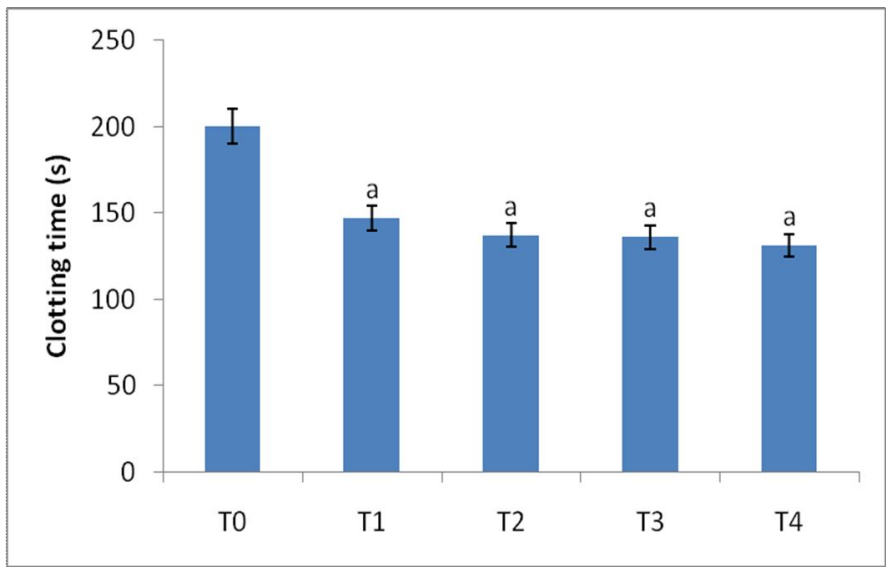

Fig. 5 : Effect of the sap of $M$. sapientum on Clotting Time.
Measurement of activated partial thromboplastin time (aPTT) aPTT's average obtained are $45 \pm 1$ seconds in all tubes. No different signification was observed between tubes which received sap and control tubes ( $\mathrm{p}>0.05)$.

\section{Time measurement of prothrombin time (PT)}

Averages obtained are $15 \pm 1 \mathrm{~s}$ in all tubes. No difference significance was observed between tubes which received sap and control tubes ( $p>0.05)$.

\section{Dosage of Total proteins}

After adding sap, there was a significant decrease ( $p$ $<0.05$ ) of the total proteins concentration in all test tubes compared to controls tubes. The decreasedpercentage in protein concentration is higher with dilutions of $20 \%$ and $25 \%$ (Fig. 6).

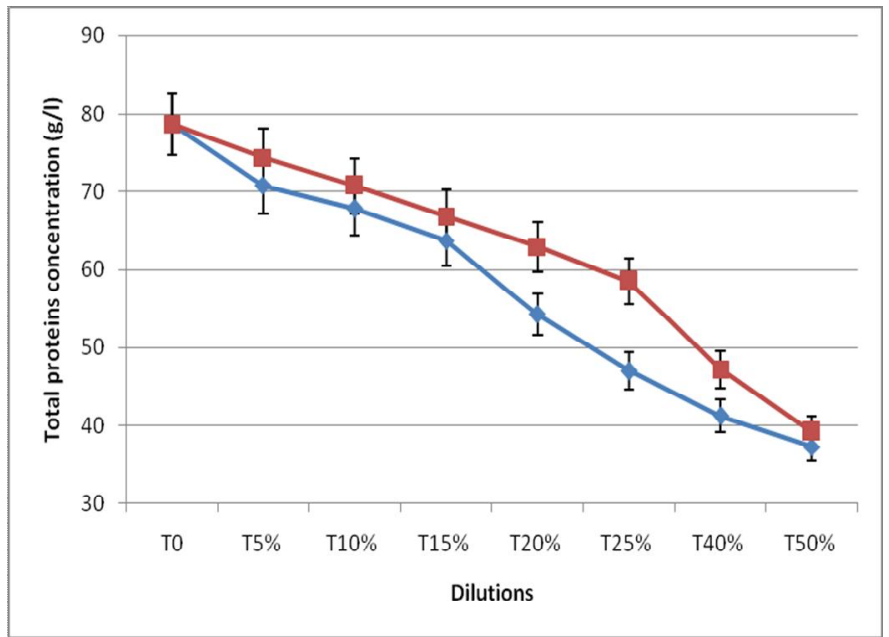

Fig.6: Effects of Musa sapientum sap on total proteins

\section{Phytochemical analyses}

The phytochemical analysis showed the presence of alkaloids, tannins, coumarins, reducing compounds, anthocyanins and leucoantocyanes.

\section{DISCUSSION}

The use of $M$. sapientum in the treatment of bleeding is very common in the South - Benin. Indeed, this plant is used as a hemostatic in Brazil (Albuquerque et al., 2007) and India (Agarwal et al., 2009; Atzingen, 2011). But this study is the first that has focused on assessing the power of hemostatic M. sapientum. The addition of sap in whole blood induced a reduction of CT significance with an effect not dose dependent. The action of sap on the CT does not appear related to the typical cascade of coagulation reactions typical of coagulation since the addition of sap in plasma did not alter the prothrombin time nor the activated partial thromboplastin time. The sap therefore has no effect on clotting factors (II, V, VII, VIII, IX, X, XI, XII and XIII) of both intrinsic and extrinsic ways (Hoffman and Monroe, 2007). This particular mechanism of action registered sap in the same category as the hemostatic with nonspecific action on the coagulation 
cascade (Abaut and Basle, 2008). The decreasing proteins concentration in the supernatant serum after the addition of sap indicates that proteins have become networks. This interaction between sap-protein seems linked to the presence of tannins in the sap. Studies on the hemostatic properties of Jatropha multifida and Annonasenegalensis have already underlined the role of tannins on the blood proteins. Indeed, the tannins have the ability to transform certain soluble proteins insoluble because of the chemical bonds that develop between them and the tannins (Wolberg, 2007). They are bristling with phenolic hydroxyl groups capable of reacting with strong hydrogen bonds with the atoms of the peptide binding protein (Crozier et al., 2009) which rendered insoluble proteins increases blood viscosity and inhibit the movement of red blood cells. That's what facilitates their aggregation (Bishop et al., 2000). Like fibrin, we believe that the protein network formed behaves like a net that traps red blood cells but also platelets and leukocytes (Wolberg, 2007). The cell aggregation has a significant effect on hemodynamics in vivo (Bishop et al., 2000). Increased aggregation produced locally in each capillary will immediately disrupt blood flow (Mchedlishvili et al., 2002). This could lead to a reduction in time and volume of bleeding. The haemostatic effect of sap can be enhanced by its astringent properties. Indeed astringent activity favors vasoconstriction, which is an important parameter in hemostasis.

\section{CONCLUSION}

The traditional use of sap of $M$. sapientum in the treatment of bleeding is warranted. And its mechanism of action results from a part of it causes vasoconstriction and secondly from the formation of a protein network that serves as a focal point to cell aggregation and the bleeding stops.

\section{ACKNOWLEDGEMENT}

Our thanks to the Ministry of Higher Education and Scientific Research of Benin, which has allowed the realization of this study through the allocation that we granted by Order No. 092/MESRS/CAB/DC/SGM/DRFM/DRH/ST-REGIE of $23^{\text {rd }}$ February 2012.

\section{REFERENCES}

Adewoye E.O., Igev A.O., Latonav C.T. Effect of methanolic extract of Musa sapientum leaves on gastrointestinal transit time in normal and alloxan induced diabetic rats: possible mechanism of action. Niger $\mathbf{J}$ Physiol Sci. 2011; 26, 83-88.

Adewoye E.O., Taiwo V.O., Olayioye F.A. Anti-oxidant and anti-hyperglycemic activities of Musa sapientum root extracts in alloxaninduced diabetic rats. Afr J Med Med Sci. 2009; 38, 109-117.
Abaut A-Y., Basle B., Les agents hémostatiques chirurgicaux. Pharm. Hosp. 2008; 43, 2-8.

Agarwal P.K., Singh A., Gaurav K., Shalini G., Khanna H.D., Goel R.K. Evaluation of wound healing activity of plantain banana (Musa sapientum var. paradisiaca) in rats. Indian J. Exp. Biol 2009; 47, 32-40.

Akoègninou A, Van der Burg WJ, Van der Maesen LJG. Flore analytique du Bénin, Backhuys Publishers, Wageningen, Netherlands (2006) 900-1043.

Albuquerque U.P., Mederios P.M., Almeida A.L., Monteiro J.M., Freitas Lins Neto E.M., Melo J.G., Santos J.P.Medicinal plants of the caatinga (semi-arid) vegetation of NE Brazil: A quantitave approach. J. Ethnopharmacol. 2007;114, 325-354.

Atzingen D.Gel from unripe Musa sapientum peel to repair surgical wounds in rats. Acta Cir. Bras. 2011; 26:5, 379-382.

Bishop J.J., Name P.R., Popel A.S., Intaglietta M., Johnson P.C. Effects of erythrocyte aggregation on velocity profiles in venules. Am. J. Physiol.2000; 280, H1460.

Borges M.H., Alves D.L.F., Raslan D.S., Pilo-Veloso D., Rodrigues V.M., Homsi-Brandeburgo M.I., Lima M.E. Neutralizing properties of Musa paradisiaca L. (Musaceae) juice on phospholipase A2, myotoxic, hemorrhagic and lethal activities of crotalidae venoms. J. Ethnopharmacol.2005; 98, 21-29.

Crozier A., Jaganath I.B., Clifford M.N. Dietary phenolics: Chemistry, bioavailability and effects on health. Nat. Prod. Rep.2009; 26(8): 1001-1043.

De Souza S. Flore du Bénin: Noms des plantes dans les langues nationales béninoises. Tome 3. Imprimerie Notre Dame, Bénin (1988) 212- 424.

Dikshit P., Shukla K., Tyagi M.K., Garg P., Gambhir J.K., Shukla R. Antidiabetic and antihyperlipidemic effect of stem of Musa sapientum Linn. in streptozotocin-induced diabetic rats. J. Diabetes. 2012; 1753-1758.

Fagbemi J.F., Ugoji E., Adenipekun T., Adelowotan O. Evaluation of the antimicrobial properties of unripe banana (Musa sapientumL.), Lemon grass (Cymbopogon citratus S.) and turmeric (Curcuma longa L.) on pathogens. Afr. J. Biotechnol. 2009; 8(7): 11761182.

Hoffman M., Monroe D.M. Coagulation 2006: A Modern View of Hemostasis. Hematol. Oncol. Clin. North. Am. 2007; 21, 1-11.

Houghton P. J., Raman A. Laboratory handbook for the fractionation of natural extracts. Ed Chapman and Hall. New York (1998), p.208.

McHedlishvili G., Varazashvili M., Gobejishvili L. Local RBC aggregation disturbing blood fluidity and causing statis in microvessels. Clin. Hemorheol. Microcir. 2002; 26: 99-106.

Pannangpetch P., Vuttivirojana A., Kularbkaew C., Tesana S., Kongyingyoes B., Kukongviriyapan V. The antiulcerative effect of ThaiMusa species in rats. Phytother. Res. 2001; 15, 407-410.

Pari L., Umamaheswari J. Antihyperglycaemic activity of Musa sapientum flowers: effect on lipid peroxidation in alloxan diabetic rats. Phytother. Res. 2000; 14, 136-138.

Partha P., Hossain A.B.M.E. Ethnobotanical Investigation into the Mandi Ethnic Community in Bangladesh. Bangladesh J. Plant Taxon. 2007; 14(2): 129-145.

Prabha P., Karpagam T., Varalakshmi B., Packiavathy A.S.C. Indigenous anti-ulcer activity of Musa sapientum on peptic ulcer. Pharmacognosy Res. 2011; 3, 232-238.

Wolberg AS. Thrombin generation and fibrin clot structure. Blood Rev. 2007;21(3): 131-142. 